\title{
Gert J. J. Biesta, The Rediscovery of Teaching, Routledge: New York, NY, and London, UK, 2017; 122 pp.: ISBN: 978-1-138-67069-3
}

Reviewed by Niels ANDEREgG ${ }^{1}$

\section{The four monographs of Gert Biesta}

Biesta sees the book The Rediscovery of Teaching (Biesta, 2017) in a logical series of his three previous books. After critically discussing the question of the 'new language' of learning (Biesta, 2006), the international testing industry of student achievement (Biesta, 2010), and the desire to create education without risk (Biesta, 2013), in his fourth monograph he is working on 'a robust and explicit account on the importance of teaching and the teacher' (Biesta, 2017, p. viii).

Biesta examines the question of education, the rediscovery of what education wants to do and can do, and what it is not. Everyone

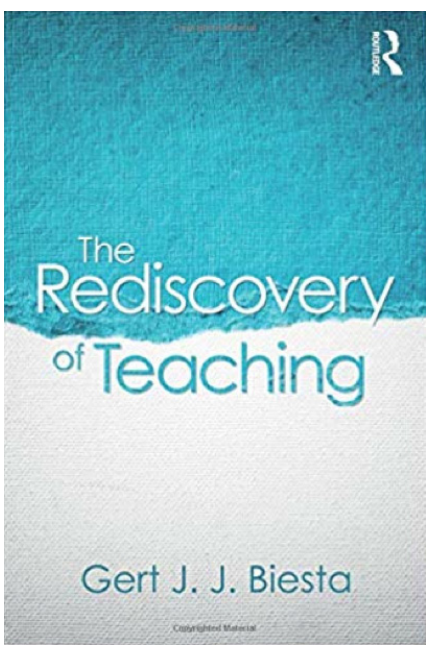
is talking about learning, and there is already a dangerous consensus that learning is central to any educational activity. However, what is meant by 'learning' is usually concealed. It seems that it goes without saying what learning means. Biesta talks about 'Learnification' and the new language about learning. This language was created in an 'age of measurement'. Learning is degraded by reducing achievement, and the student becomes an object of a risk-free process. 'Learning' or 'development' are two popular terms; however, for Biesta they are not sufficient to express what education can do. Biesta suggests the term 'formation'. The term is old and also old-fashioned. However, with the idea of formation, he expresses that education is about a 'coming into the world'. Ultimately, it is about creating existential opportunities in which students can experience the freedom to grow up as subjects in this world.

1 Center for Management and Leadership, Zurich University of Teacher Education, Switzerland; niels.anderegg@phzh.ch. 
For Biesta, schools and other educational institutions have three functions: qualification, socialisation, and subjectification. These are three contradictory functions that are connected in a field of tension. At the same time, the school is in a state of tension that Biesta calls 'the double history of the school'. On the one hand, the school has a function of and for society. With modernisation, society has lost the educational power and handed over this function to the school. On the other hand, the school is a place between 'home' and 'the street'. It is a place for practice, not for work and production. School is a place of growing up. While the one side postulates a legitimate expectation of society to the school, the other side needs to be a place that is shielded from social demands.

Teachers move in areas of tension and contradictions and manage to shape them and create a successful practice. In his latest book, Biesta discusses how this succeeds. It is neither a recipe-based didactic book nor an empirical study of successful teacher action. Biesta argues from an educational-philosophical perspective. This allows him to look 'behind the scenes' of today's discussions and to ask the question of normativity.

\section{The rediscovery of teaching}

Biesta's book deals with the question of the relationship between learning and teaching and the related question of the function and actions of teachers. He moves between two points of view: he supports the criticism of the traditional concept of teaching, but at the same time, criticises the modern idea of learning accompaniment as inadequate.

In the contemporary discussion about teaching and learning, there is criticism of the traditional concept of teaching. The discussion about constructivism shows that teaching does not automatically lead to learning. Biesta supports this view, though for different reasons. An authoritarian understanding of teaching can also be seen as control. The student becomes the object of the learning process organised by the teacher. The conclusion that teaching, in this case, is reduced to accompanying learning is also criticised by Biesta. He points out that also in this sense teaching can be considered as control. The students are responsible for their own learning, and the teachers have the task of accompanying them and at the same time checking whether they have reached the set goals. A pedagogical idea becomes a controlling function. In today's PISA age of measuring school performance, society expects the school and the teachers to meet their learning goals. One of the difficulties of seeing teaching as control is that in such a perspective, learners can only be seen as objects. At the same time, the 
idea of the student as the subject of his own learning is too short. Learning, understood as a process of interpretation and comprehension, ultimately does not allow the student to exist as a subject. Together with Emmanuel Levinas, Biesta shows that our subjectivity is not generated through our own acts of signification. Our subjectivity is rather constituted from the outside, that is, through the address of others. We never act with only ourselves. We are always in and with the world and thus are subject and object simultaneously. Biesta is ultimately concerned with a different teaching concept, which, in contrast to authoritarian teaching and in contrast to self-generated adaptive learning, should enable the subjectivity of the student. '[...] that teaching, if it is interested in the grown-up subject-ness of students, is not a matter of creating spaces where students can be free - that is, enact their freedom of signification, their freedom to learn - but it is rather about creating existential possibilities through which students can encounter their freedom, can encounter the 'call' to exist in the world a grownup way, as subject' (Biesta, 2017, p. 6). Gert Biesta shows how students' existence as subjects depends on the creation of existential possibilities, through which students can assert their grown-up place in the world.

\section{Progressive arguments for a conservative idea}

In his book, Biesta develops a pleasantly different view of the relationship between learning and teaching, between students and teachers. Learning takes place in a highly complex relationship characterised by areas of tensions, conflicts, contradictions, and dissensions. In the contemporary discussion on school policy, school development or effectiveness and educational leadership, learning is measured with the quantitative performance of students. As an alternative to this, the freedom of the student is often put in the centre. Biesta's book shows that both perspectives are short-sighted and that we cannot avoid dealing with the concept of learning and the normative question of the 'why'. This requires an examination of authors, such as Emmanuel Levinas, Paulo Freire, Hannah Arendt, or Jacques Rancière, whom Biesta refers to in his book. However, also authors such as Günther Buck, Horst Rumpf or Käte Meyer-Drawe, who deal with a phenomenological, experience learning concept in German-speaking countries, or Michael Schratz and Michael Göhlich, who make the connection between learning and organisation, should be included in this discussion.

There is another strength of Gert Biesta: as a cross-border commuter of different cultural areas, he incorporates different lines of discussion and perspectives. This makes his work feel surprising and new without being new. 
For some time, Gert Biesta toiled with the idea of giving the book the subtitle 'Progressive arguments for a conservative idea'. It has become common to see the teacher as a 'facilitator of learning. Biesta criticises this, just as he does not see the teacher as a 'manufacturer of learning'. He does not see the teacher and his work as conservative or progressive: 'that teaching is not necessarily conservative and not necessarily a limitation of the child's or the student's freedom, just as the "freedom to learn" (Rogers, 1969) is not automatically or necessarily liberating and progressive' (Biesta, 2017, p. ix). In this sense, Gert Biesta's book is neither new nor old, neither conservative nor progressive. It is a book that first asks the question 'why', before giving the answer to the 'how'. This is something self-evident, but unfortunately often lacking in today's discourse on schools and teachers.

\section{References}

Biesta, G. J. J. (2006). Beyond learning. Democratic education for a human future. Boulder, CO: Paradigm Publishers.

Biesta, G. J. J. (2010). Good education in an age of measurement: Ethics, politics, democracy, interventions: education, philosophy \& culture. Boulder, CO: Paradigm. Publishers.

Biesta, G. J. J. (2013). The beautiful risk of education. Boulder, CO, \& London, UK: Paradigm Publishers. Biesta, G. J. J. (2017). The Rediscovery of teaching. New York, NY, \& London, UK: Routledge. 